\title{
HER NAME WAS JANE
}

\section{Remembrance day.}

BY JOSES HO

$\mathrm{M}$

y name is Noah. I'm going to start writing, because I'm following the only piece of advice that I can clearly recall. I heard it from a cab driver as I rode in his taxi. He said: "The people you write about should be the ones who you dream about."

Jane and I, as I remember, might have been chatting about our favourite authors, something along those lines, I'm not sure. We both looked up at the taxi driver's eyes, dimly reflected through the rear-view mirror.

"Do you write stories in your spare time?" I can't recall which one of us asked him that, Jane or I, but I remember thinking: "Now we're getting drawn into a conversation with a stranger. This might not bode well for a first date."

To be honest, I'm not sure which date Jane and I were on. I know it was our last.

"I used to write." He continued looking at us through the mirror as we sped along. "Non-fiction, though. Papers. Quite a few. Scientific ones."

His eyes turned back to the road, and he said: "It wasn't too long ago either. Two or three years. Or maybe two or three months."

"What do you mean?" He turned his face back, and I think his eyes met mine.

"Do you really want to know?"

I said, half-laughing: "Well, now you have to tell us, right?" I turned slightly to look at Jane, but I can't recall what her expression was.

The taxi driver turned back, and said: "Well, then I guess I'll show you." I don't think he said anything else for the rest of the journey. Jane and I probably just sat in awkward silence until we reached her place, and I don't think I bothered to talk to the driver as he drove me back to mine.

And, as I recall, that night the dreams started.

Those first dreams, I remember, were of my childhood - happy days with my older sister Karen. We would hide from the torrential rain, squeezing into our dollhouse, giggling like the pre-adolescent girls we were as Mother screamed over the downpour: "Karen! Jane! Come back inside!" The funny

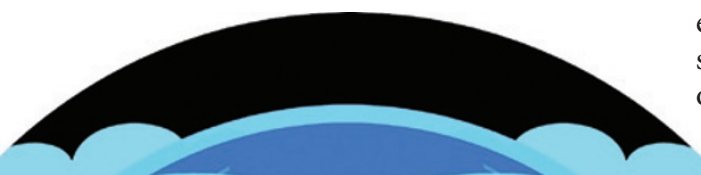

epigenetic modifications to DNA. Genes 긴 shutting each other down, turning each 학 other on, rewiring the brain, creating memories and erasing others. And I knew, with a few tweaks to those equations I had just seen, you could transmit the quantum signature of one neuronal epigenome to another. In other words, you could clone memories.

The thing is, if you check my passport, I've never been to France in my entire life. And I don't know what the hell the word 'epigenetic' means. And I can remember flying back and living in my lab for the next few months, despite the constant warnings from the institute that they would kick me out. And when they did, I recall being shunned by every university I sought a position with.

I remember screaming at my wife and kids as they left the apartment with their luggage, insisting that this night-shift cabbie work would tide us over, don't give up on me now, please, I'm this close to making it work. And then I see myself, waking up, hungover again, stumbling down to the taxi and rewiring the coils into the chassis, knowing there was only one way to find out if it did work.

Last night I dreamt that there's a cabal of cabbies, driving electromagnetic taxis around the city, secretly homogenizing the histories of random strangers. Because driving a taxi's the easiest way to get people to climb into a $7 \mathrm{~Hz}$ field for at least 15.3 minutes. That's all the time needed to swap your memories with someone else.

You see, there's only one way to know which of your memories are real. You compare them with newer dreams, ones you're sure you've never had before. So I'm taking my advice, writing all of this down, so that I can sort out all these dreams. Because I'm not sure, anymore, which of these memories are actually mine.

I don't see her in my dreams anymore — and I'm not even sure if her name was Jane.

And I remember strolling down the $\rightarrow$ NATURE.COM in my thoughts. The Follow Futures on biological basis of Facebook at: memory, I reasoned, go.nature.com/mtoodm could be explained by
Joses Ho is pursuing a DPhil at the

University of Oxford, UK. He was born and bred in Singapore. Follow him on Twitter at www.twitter.com/jacuzzijo. 